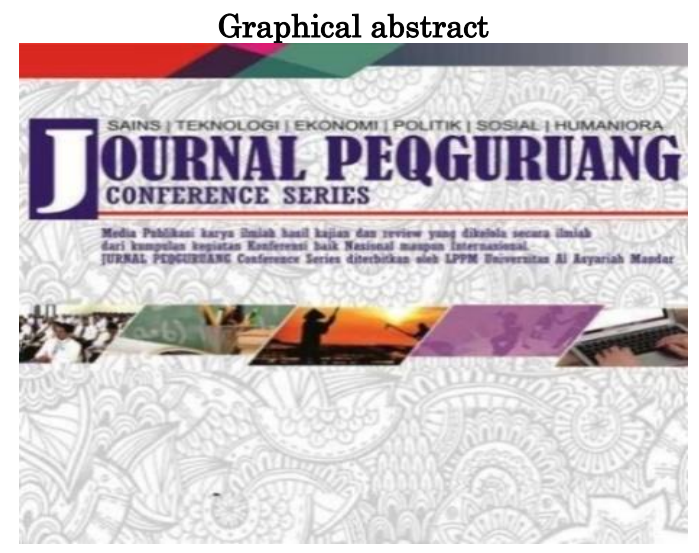

\title{
IMPLEMENTASI PENGANGATAN DAN PEMBERENTIAN PERANGKAT DESA
}

\author{
${ }^{1 *}$ Nurpadlan, ${ }^{2}$ Abd.khalik, ${ }^{3}$ Hamdan \\ ${ }^{123}$ Universitas Al Asyiariah Mandar
}

Corresponding author

Nurpadlan028@gmail.com

Abstract

This study aims to determine how the Implementation of Appointment and Dismissal of Village Apparatus. This type of research is a qualitative research using descriptive method. The data in this study is the dismissal and appointment of village officials in accordance with local regulations. The data sources use primary and secondary. Data collection techniques in this study are interviews, observation. Research results 1) Communication. Communication procedures from Kenje village officials have met the criteria, and provide comfort to the community, but sometimes Kenje village officials are more concerned with the family. 2) Human Resources. The existing resources in Kenje Village have met competent standards for the future progress of Kenje Village. 3) Implementing Attitude Resources. Implementors do not know what to do and have the ability to implement the policy, but they must also have the will to implement the policy. 4) Bureaucratic Structure. SOPs are very likely to become obstacles for new implementations that require new ways of working or new types of personnel to implement policies.

Keywords: Appointment and Dismissal of Village Apparatus

\section{Abstrak}

Pemeriksaan ini bermaksud untuk memutuskan bagaimana Pelaksanaan Pengangkatan dan Pemberhentian Perangkat Desa. Eksplorasi semacam ini merupakan pengujian subjektif dengan menggunakan strategi yang menarik. Informasi dalam penyelidikan ini adalah alasan dan pengaturan otoritas kota sesuai pedoman lingkungan. Sumber informasi memanfaatkan esensial dan opsional. Metode pengumpulan informasi dalam penelitian ini adalah wawancara, persepsi. Hasil Eksplorasi 1) Komunikasi. Strategi korespondensi dari pemerintah kota Kenje telah memenuhi model dan memberikan penghiburan kepada daerah setempat, namun kadang-kadang pemerintah kota Kenje lebih khawatir tentang keluarga. 2) Sumber Daya Manusia. Aset-aset yang ada di Desa Kenje saat ini telah memenuhi pedoman yang mampu untuk kemajuan Desa Kenje di masa depan. 3) Menerapkan Sumber Daya Sikap. Praktisi tidak hanya menyadari apa yang harus dilakukan dan dapat melaksanakan pengaturan, tetapi mereka juga harus memiliki kemauan untuk melaksanakan strategi tersebut. 4) Struktur Birokrasi. SOP mungkin akan menjadi penghalang bagi pelaksanaan baru yang membutuhkan pendekatan yang lebih baik untuk bekerja atau jenis fakultas baru untuk melakukan pengaturan

Kata Kunci : Pengangkatan dan Pemberhentian Perangkat Desa

\section{Article history}

DOI: https://dx.doi.org/10.35329/ip.v3i2.2399

Received : 18 Agustus 2021 | Received in revised form : 20 September 2021 | Accepted : 17 November 2021 


\section{PENDAHULUAN}

Kota sebagai susunan organ pemerintahan yang terkecil dan terkecil dalam struktur kewenangan publik, mempunyai kewajiban dan komitmen untuk mengkoordinasikan pemerintahan di ruangnya dengan tujuan agar kota mempunyai kewajiban dan kedudukan untuk melakukan perancangan saat ini di kota dimana kota tersebut berada. kerangka dijalankan, didorong langsung oleh kepala kota. di samping perakitan mekanik kota di bawah mereka, membuat kota siap untuk menjalankan keluarganya sendiri. Untuk menghadapi penyelenggaraan pemerintahan negara bagian hingga ke seluruh pelosok tanah air, maka penting untuk membingkai pemerintahan daerah. Pemerintah terdekat mengkoordinasikan pemerintahan yang langsung diidentikkan dengan daerah (HR, Syaukani, 2005:21).

Perubahan signifikan lainnya adalah pemberian hak kepada daerah untuk membuat pedoman provinsi dan pedoman yang berbeda untuk melakukan pemerintahan sendiri dan membantu usaha (Ni'matul Huda, 2009:13). Salah satu yang memiliki self-governance adalah kota. Kota adalah pembagian domain manajerial di Indonesia di bawah sub-daerah yang dipimpin oleh kepala kota. Perkembangan kota dimulai dengan penataan perkumpulan lokal karena naluri manusia sebagai makhluk yang bersahabat, motivasi normal, atau elemen lingkungan manusia, kepentingan normal dan risiko luar. Untuk mengetahui administrasi publik yang sesuai dengan kebutuhan pemerintah kota dan pembuatan struktur wilayah kota yang dapat dimanfaatkan secara tepat dan berkualitas, penting untuk memiliki SDM yang cakap dan keterampilan yang dapat dibuktikan kerja untuk membuat administrasi publik dengan memperluas mekanik aset perakitan di tingkat kota. menjadi vital dan berubah menjadi hal utama. Perangkat kota memiliki tugas membantu kepala kota dalam melakukan kewajiban dan keahlian kepala kota, sehingga berdasarkan standar pedoman, metode penamaan otoritas kota perlu membuat prasyarat untuk pengaturan otoritas kota, panjang kantor, aliran keuangan, elemen utama dari tugas, hal - Hal-hal yang tidak boleh diabaikan selama kantor dan sistem. Dalam memilih hubungan yang berfungsi antara Kepala Desa dan Perangkat Desa tidak perlu mengikutsertakan kepentingan individu dan sentimen tertentu dikarenakan apabila melibatkan suatu kepentingan tertentu akan menimbulkan berbagai hal yang tidak menguntungkan, misalnya pertentangan dan perebutan hukum antara kepala kota dan perangkat kota termasuk. Eksekusi adalah gerak maju dari latihan untuk menyampaikan pengaturan ke daerah setempat dengan tujuan agar strategi tersebut dapat membawa hasil yang benar ke bentuk (Gaffar, 2009: 295). mengklarifikasi pentingnya eksekusi ini dengan mengatakan bahwa: mendapatkan apa yang sebenarnya terjadi setelah program dinyatakan berhasil atau ditentukan adalah penekanan pertimbangan pada eksekusi strategi, dalam kesempatan tertentu dan latihan yang muncul setelah penerimaan aturan strategi negara, yang menggabungkan keduanya berusaha untuk mengawasinya hanya untuk menimbulkan hasil/dampak nyata pada masyarakat atau peristiwa (Wahab, 1997: 64-65).

Makna eksekusi di atas jika dikaitkan dengan strategi adalah bahwa sebenarnya pendekatan tersebut tidak hanya direncanakan dan kemudian dibuat dalam struktur yang positif, misalnya suatu undang-undang dan kemudian didiamkan dan tidak dilakukan atau dilaksanakan, namun suatu pengaturan harus dilakukan. keluar atau dieksekusi untuk memiliki efek atau tujuan yang ideal. Eksekusi strategi adalah suatu pekerjaan untuk mencapai tujuan tertentu dengan cara tertentu dan dalam pengelompokan waktu tertentu (Sugiono 1994:137). Selanjutnya, aset perakitan mekanik harus diawasi dengan tepat untuk membangun kecukupan dan produktivitas asosiasi pemerintah untuk memahami keterampilan perwakilan yang dipoles dalam menyelesaikan pekerjaan mereka. Hal ini sesuai dengan pandangan Soeworno bahwa: Majelis mekanis adalah sudutsudut pengaturan yang diperlukan dalam penyelenggaraan pemerintahan atau negara, sebagai instrumen untuk mencapai tujuan umum. Bagian dari paguyuban, khususnya paguyuban atau kepegawaian (Soewarno, 1982:154). Sesuai dengan aset perakitan mekanik masa lalu, untuk memahami keterampilan pekerja yang dipoles, bahwa seorang ahli adalah spesialis, tugas yang cocok di bidangnya, dan dilihat dari posisinya. posisi yang ditunjuk untuknya. Tugas yang diberikan kepada individu harus diwakili, mengingat fakta bahwa komitmen harus dilakukan dan pekerjaan yang diberikan kepadanya tidak boleh ditinggalkan sebelum pekerjaan selesai.

\section{METODE PENELITIAN}

\section{A. Teknik Pengumpulan Data}

Informasi merupakan sesuatu yang tidak memiliki arti penting bagi penerima manfaat dan masih memerlukan penanganan. Informasi dapat berupa keadaan, gambar, suara, huruf, angka, ilmu pengetahuan, bahasa atau gambar lain yang dapat kita gunakan sebagai bahan untuk melihat iklim, barang, peristiwa atau ide.

Pemilahan informasi dilakukan untuk mendapatkan data yang diperlukan untuk mencapai tujuan pemeriksaan. Tujuan yang dikomunikasikan sebagai teori adalah tanggapan singkat untuk menyelidiki pertanyaan. Mengumpulkan informasi menggunakan prosedur pertemuan, review dan persepsi. Dalam pengujian ini, pencipta memanfaatkan informasi yang bersifat purposive seperti yang ditunjukkan oleh target eksplorasi. 
Strategi bermacam-macam informasi akan diselesaikan dengan:

\section{Wawancara}

Meeting adalah suatu strategi untuk mengumpulkan informasi dengan menanyakan sesuatu kepada responden, tekniknya adalah dengan berdiskusi secara dekat dan personal. Dalam investigasi ini, rapat akan dipimpin dengan menggunakan aturan rapat.

Menurut Patton, dalam pemutaran menggunakan panduan rapat ini, rapat dilengkapi dengan panduan rapat yang sangat luas, dan mencakup hal-hal yang harus dibahas tanpa menentukan permintaan pertanyaan, mungkin pertanyaan cepat tidak berbentuk.

Panduan pertemuan digunakan untuk mengingatkan si penanya perspektif apa yang harus diperiksa, sebagai agenda apakah sudut pandang penting telah dibicarakan atau ditanyakan. Dengan aturan-aturan ini, penanya harus merenungkan bagaimana inkuiri akan digambarkan secara kokoh dalam kalimat inkuisitif, seperti halnya mengubah inkuiri ke setting asli selama pertemuan..

1. Observasi

Selain wawancara, pemeriksaan ini juga menggunakan teknik persepsi. Menurut Patton, persepsi adalah persepsi metodis dan rekaman komponen-komponen yang muncul dalam suatu manifestasi atau efek samping pada objek eksplorasi. Dalam pengujian ini, persepsi seharusnya sudah siap untuk memahami jalannya pertemuan dan konsekuensi dari pertemuan dapat dirasakan dalam situasi yang unik. Persepsi yang akan dilakukan adalah persepsi subjek, perilaku subjek selama pertemuan, kerjasama subjek dengan analis dan hal-hal yang dipandang penting sehingga dapat memberikan informasi tambahan tentang konsekuensi pertemuan. Motivasi di balik persepsi adalah untuk menggambarkan latar yang direnungkan, latihan yang terjadi, individu yang terlibat dengan gerakan, dan makna peristiwa yang dilihat menurut sudut pandang mereka yang ditemukan dalam peristiwa yang diamati. Macam-macam Pengamatan:
a. Observasi partisipatif
b. Observasi terus terang atau tersamar
c. Observasi tak berstuktur

\section{B. Teknik Analisis Data}

Penyelidikan informasi adalah cara paling umum untuk mengatur pengelompokan informasi, menyusunnya menjadi contoh, kelas dan penggambaran mendasar yang mengenalinya dari pemahaman, secara spesifik memberikan signifikansi kritis untuk pemeriksaan, memperjelas penggambaran dan mencari hubungan antara elemen dari penggambaran. Untuk menelaah informasi, penyusun menggunakan penelusuran informasi dengan menggunakan uji klarifikasi, artinya informasi yang dirinci tidak menggunakan informasi faktual, tetapi hanya menggunakan perkiraan yang tepat, sehingga hasilnya solid dan substansial.

\section{HASIL PENELITIAN}

Mengingat efek lanjutan dari eksplorasi masih di udara di lapangan bahwa variabel penghambat dalam memahami pengaturan dan izin otoritas kota yang baik di kota Kenje, wilayah Campalagian, adalah SDM dibandingkan dengan perakitan mekanik pemerintah kota Kenje yang sangat lemah. Hal ini ditegaskan dengan kegagalan majelis mekanik pemerintah kota dalam mencari pemerintah kota Kenje untuk melakukan pengaturan dan pelepasan otoritas kota sesuai teknik

1. Komunikasi

Komunikasi dalam Pelaksanaan Pengangkatan dan Pemberhentian Aparatur Desa di Desa Kenje adalah penyampaian data strategi dari produsen strategi kepada pelaksana strategi dan dibuat menarik lagi dengan meneruskannya ke kumpulkumpul sasaran strategi dan individu investasi lainnya. Penanda dalam korespondensi adalah jalannya transmisi/pengarahan korespondensi kejernihan, korespondensi dan konsistensi.

2. Sumber daya

Aset lain yang sangat penting dalam menentukan pencapaian eksekusi strategi adalah otoritas. 1. SDM. SDM merupakan salah satu faktor yang mempengaruhi pencapaian eksekusi strategi. 2. Menghabiskan aset. Pengeluaran aset berdampak pada pencapaian eksekusi dan strategi. 3. Aset perangkat keras.

Merupakan sarana yang digunakan untuk operasionalisasi implentasi suatu kebijakan yang meliputi gedung, tanah, dan sarana yang semuanya akan bekerja sama dalam menawarkan jenis bantuan dan melaksanakan pendekatan. 4. Aset kekuasaan. Penghibur strategi prinsip harus diberi kekuatan yang memadai untuk menentukan pilihan mereka sendiri untuk menjalankan strategi di bawah posisi mereka.

1. Sumber Sikap Pelaksana (disposis)

Eksekusi akan berhasil dengan sukses dan efektif, para pelaksana tidak hanya menyadari apa yang harus dilakukan dan dapat melakukan strategi, tetapi mereka juga harus memiliki kemauan untuk melakukan pendekatan tersebut.

2. Struktur Peraturan

Meskipun aset untuk menjalankan strategi memadai dan pelaksana menyadari apa dan bagaimana melakukannya, dan ingin melakukannya, SOP mungkin akan menjadi hambatan untuk eksekusi baru yang memerlukan pendekatan yang lebih baik untuk bekerja atau jenis staf baru untuk melaksanakannya. pengaturan. Oleh karena itu, semakin penting pengaturan tersebut memerlukan perubahan perilaku yang khas dalam suatu asosiasi, semakin besar kemungkinan bahwa SOP yang menggagalkan pelaksanaan rancangan peraturan 
yang terbagi (terpecah atau terpencar) dapat menimbulkan kekecewaan korespondensi, dengan alasan bahwa peluang pedomannya dimutilasi sangat besar. Eksekusi pendekatan yang lebih bengkok, koordinasi yang lebih meningkat diperlukan.

Berikutnya adalah gambaran dari konstruksi otoritatif pemerintah kota Kenje.

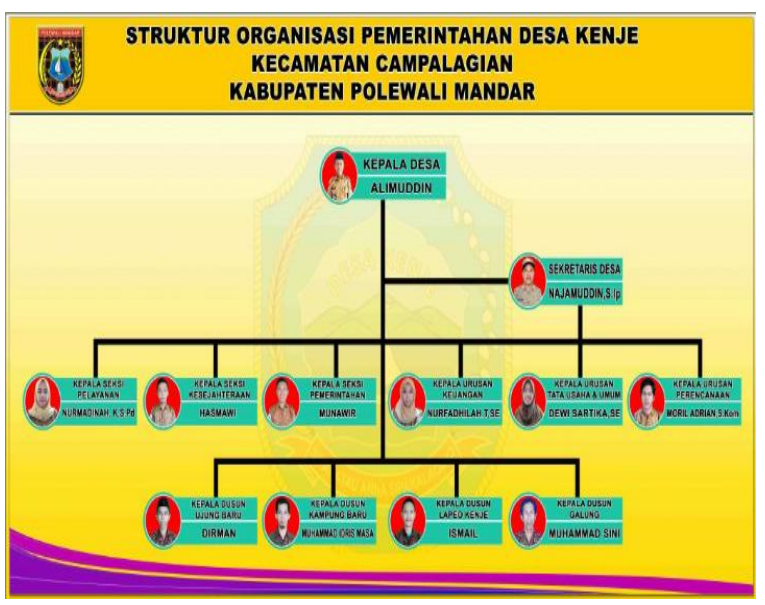

Perangkat kota adalah salah satu hal penting dalam sebuah kantor, karena jika tingkat disiplin perwakilan meningkat, semakin tinggi pameran perwakilan dan bekerja tanpa disiplin dari pekerja, tidak dapat disangkal tantangan bagi organisasi untuk mencapai hasil yang ideal. Disiplin kerja sangat dibutuhkan oleh setiap pekerja, disiplin merupakan prasyarat untuk pengembangan mentalitas, perilaku dan kehidupan yang terlatih yang akan memudahkan perwakilan untuk bekerja, sehingga menciptakan lingkungan kerja yang baik dan mendukung upaya untuk mencapai tujuan.

1. Jalannya Penataan dan Persalinan Aparatur Desa Kenje Kecamatan Campalagian.

dibayangkan atau sulit dilakukan. Kepala kota harus memiliki pilihan untuk lebih memahami kewajiban dan kemampuannya dalam menata kembali perangkat kotanya selama waktu yang dihabiskan Pengangkatan dan Pemberhentian Perangkat Desa Berdasarkan Perda No. Campalagian Kabupaten Polewali Mandar adalah bahwa belum ada kepentingan rumah dan surat-menyurat, dengan asumsi pengaturannya tergantung pada kepentingan, menjadi batas jika gadget yang disebutkan tidak memenuhi persyaratan atau tidak dilengkapi untuk bekerja, jika karena kepentingan dan kedekatan seperti ada koneksi, alasan sebagai sejauh atau alasan dimaafkan atau tidak, bila dilakukan secara efektif majelis mekanik kota dalam melakukan kewajiban dan kapasitasnya secara tepat dan dapat diandalkan serta dapat melayani daerah secara maksimal.

\section{Teori Implementasi George C. Edward III}

a. Komunikasi

Faktor utama yang mempengaruhi korespondensi strategi adalah transmisi. Penyampaian surat menyurat atau penyebaran surat menyurat yang baik sebenarnya ingin membuat pelaksanaan yang baik pula. Pelaksanaan penataan dan pelepasan kewenangan kota akan memberikan hasil yang ideal apabila dilakukan sesuai Peraturan Daerah Nomor 06 Tahun 2017 tentang Perangkat Desa.

Faktor selanjutnya adalah kejelasan. Petunjuk kejelasan korespondensi juga merupakan komponen penting. Kejernihan korespondensi akan menentukan keberhasilan pelaksanaan pengaturan publik. Dengan asumsi pendekatan-pendekatan yang dilakukan sesuai dengan yang diharapkan, maka arah pelaksanaannya tidak boleh hanya diketahui oleh para pelaksana penataan, namun juga kesesuaian strateginya harus jelas. Ketidakjelasan pesan korespondensi yang disampaikan sehubungan dengan pelaksanaan pendekatan akan memperkuat kesan palsu dan bahkan mungkin berbenturan dengan pentingnya pesan pertama.

Mengingat konsekuensi dari pertemuan yang diarahkan, pencipta membedah bahwa transmisi korespondensi atau sirkulasi korespondensi, dan kejelasan korespondensi oleh individu yang bersangkutan sangat berjalan dengan baik.

b. Sumber daya

Keterbukaan dan sifat staf dalam pemeriksaan ini adalah tentang ketersediaan kelompok yang dapat digunakan untuk menyelesaikan tugas-tugas tertentu dari spesialis hingga eksekusi.

Peraturan Daerah Nomor 06 Tahun 2017 tentang Pengangkatan dan Pemberhentian Perangkat Desa.

Pencipta merinci secara kuantitatif, keterjangkauan kuantitas SDM sebagai tim pelaksana Peraturan Daerah Nomor 06 Tahun 2017 tentang Pengangkatan dan Pemberhentian Perangkat Desa yang jumlahnya memadai, khususnya 10 orang.

c. Terletak

Sikap pemeriksaan ini adalah tentang tanggung jawab. Tanggung jawab tersebut ditunjukkan dengan mencermati penjelasan di balik pelaksanaan pelaksanaan, tujuan/perubahan yang ingin dicapai, dan perkembangan yang telah dicapai para praktisi atas pelaksanaan Peraturan Daerah Nomor 06 Tahun 2017 tentang Pengangkatan dan Pemberhentian Aparatur Desa. Pelaksanaan Peraturan Daerah Nomor 06 Tahun 2017 tentang Pengangkatan dan Pemberhentian Perangkat Desa bertujuan untuk menciptakan penguasa kota yang berakhlak dan bermoral.

d. Struktur Peraturan

Pada bagian desain regulasi, Desa Kenje saat ini memiliki konstruksi administrasi yang bekerja sama dengan divisi usaha. Desa Kenje memiliki desain peraturan yang jelas dan telah mengikuti SOP yang benar 


\section{SIMPULAN}

Mengingat akibat dari penjajakan dan pembicaraan yang telah dilakukan oleh para ahli sehubungan dengan pelaksanaan Pengangkatan dan Pemberhentian Perangkat Desa di Desa Kenje Kecamatan Campalagian dapat ditarik kesimpulan sebagai berikut:

a. Komunikasi

Korespondensi benar-benar menentukan pencapaian pencapaian tujuan melakukan pendekatan terbuka. Pelaksanaan penataan dan pelepasan otoritas kota di Desa Kenje telah berhasil dan sesuai dengan pedoman setempat, karena kepala desa pasti tahu apa yang akan mereka lakukan.

b. Sumber daya

Dalam suatu pelaksanaan, data yang disampaikan dapat menjadi jelas dan dapat diprediksi karena aksesibilitas staf yang cakap, aksesibilitas kantor dan yayasan yang memadai serta rencana keuangan yang tepat dan waktu untuk menyelesaikan pelaksanaan Pengangkatan dan Pemberhentian sehingga pelaksanaan pengecualian dan pengaturan otoritas kota berjalan dengan baik.

c. Disposisi Pelaksana

Setiap staf memiliki tanggung jawab dan disiplin pejabat dalam menjalankan kewajibannya.

d. Konstruksi birokrasi.

Para pelaksana strategi pasti menyadari apa yang harus dilakukan dalam menjalankan Perda Nomor 06 Tahun 2017 tentang Pengangkatan dan Pemberhentian Perangkat Desa di Desa Kenje Kecamatan Campalagian.

\section{DAFTAR PUSTAKA}

Gaffar. 2009. Politik Indonesia: Transisi Menuju Demokrasi. Yogyakarta: Pustaka Pelajar.

Ni'matul, 2009, Otonomi Daerah Filosofi, Sejarah Perkembangan dan Problematika, Pustaka Pelajar, Yogyakarta.

Ni'matul Huda, Otonomi Daerah, (Pustaka Pelajar: Yogyakarta, 2009), Cet ke-2.

Sugiyono (2011). Metode penelitian kuntitatif kualitatif dan R\&D. Alfabeta.

Sugiyono. 2012. Metode Penelitian Kuantitatif Kualitatif dan R\&D. Bandung.

Sugiyono. (2017). Metode Penelitian Kuantitatif, Kualitatif, dan R\&D. Bandung.

Soewarno. 1982. Pengantar Studi Ilmu Administrasi dan. Management. Jakarta: PT Inti Idayu Press.

Syaukani. HR, Afan Gaffar, Ryaas Rasyid. MA, 2004. Otonomi Daerah Dalam Negara Kesatuan. Yogyakarta: Pustaka Pelajar.

UU Nomor 6 Tahun @014 Tentang Desa.

Wahab (1997). Analisis kebijaksanaan, dari Formulasi Ke implementasi kebijaksanaan Negara,Jakarata 